\title{
Accuracy of different endometrial swabbing techniques in the mare
}

\author{
Kim-Carolin Spilkerl,2, Jutta Sielhorst ${ }^{1,3}$, Gunilla Martinsson², Sebastian Pricking ${ }^{1,2}$, Wolfgang Hasslert, Reinhard Böse ${ }^{5}$, Karl Rohn ${ }^{6}$ \\ und Harald Sieme ${ }^{7}$ \\ ${ }^{1}$ Clinic for Horses- Unit for Reproductive Medicine, University of Veterinary Medicine Hannover, Foundation, Hannover, Germany \\ ${ }^{2}$ National State Stud Lower Saxony, Celle, Germany \\ 3 Veterinary Clinic Domaene Karthaus, Duelmen, Germany \\ ${ }^{4}$ Veterinary Practice Papenburg, Germany \\ ${ }^{5}$ Laboratory Dr. Böse GmbH; Harsum, Germany \\ ${ }^{6}$ Institute of Biometry, Epidemiology and Information Processing, University of Veterinary Medicine Hannover, Foundation, Hannover, Germany
}

\begin{abstract}
Summary: Early diagnosis of endometritis and identification of pathogens involved are essential to choose the correct treatment and optimize fertility in the mare. The objective of this study was to compare results from endometrial swabs taken through the vagina manually, by speculum and forceps, and by iVetscope ${ }^{\circledR}$, a recently introduced rigid endoscope equipped with a monitor and two working channels, to identify the most reliable swabbing technique. Endometrial swabs for microbioloy and cytobrush samples to assess endometrial cytology were obtained from 88 estrous mares in a commercial breeding program by three different sampling techniques. Following a gynecological examination endometrial samples were taken transvaginally using a double-guarded uterine culture swab and cytobrush manual (MAN) $(n=29)$, a speculum (SPEC) $(n=30)$ or iVetscope ${ }^{\circledR}(S C O P)(n=29)$. Endometrial swabbing was repeated after $48 \mathrm{~h}$. The culture results assessed in an internationally accredited laboratory were related to the endometrial cytology (>5 PMNs/10 HPF). The three different sampling methods showed significant differences in bacterial growth, especially in the second sampling after 48 hours. While $28 / 29,97 \%$ of MAN-samples showed bacterial growth, bacteria were isolated from 22/29, $76 \%$ of SPEC- and 20/30, 67\% of SCOP-samples (p<0.05). Facultative pathogenic bacteria were significantly more often isolated from samples taken manually $(16 / 29,55.2 \%)$ than samples taken by speculum $(5 / 29,17.2 \%)$ or iVetscope ${ }^{\circledR}(4 / 30,13.3 \%) 48$ hours after the first sampling $(p<0.05)$. An increased number of samples with bacterial growth of more than three bacterial species in the first and second swab $(31 \%$ and $37.9 \%$ in the MAN-group versus $3.3 \%$ and $0 \%$ in the SCOP-group and $0 \%$ and $6.9 \%$ in the SPEC-group at the first and second sampling, respectively; $p<0.01$ ) reveals bacterial contamination from the caudal reproductive tract in swabs taken via the transvaginal manual approach. These results strongly recommend endometrial swabbing by instrumental techniques (speculum and forceps, or iVetscope ${ }^{\circledR}$ ). Although, these swabbing techniques might be slightly more time consuming and require more material, the significantly reduced bacterial contamination underlines the relevance of the swabbing technique in equine practice.
\end{abstract}

Keywords: mare, uterus, endometrial swabbing, bacterial contamination, microbiology, cytology, reproduction

Citation: Spilker K.-C., Sielhorst J., Martinsson G., Pricking S., Hassler W., Boese R., Rohn K., Sieme H. (2017) Accuracy of different endometrial swabbing techniques in the mare. Pferdeheilkunde 33, 172-178; DOI 10.21836/PEM20170210

Correspondence: Prof. Harald Sieme, University of Veterinary Medicine Hannover, Foundation, Clinic for Horses- Unit for Reproductive Medicine, Bünteweg 930559 Hannover, Germany; E-mail: harald.sieme@tiho-hannover.de

\section{Introduction}

Endometritis is diagnosed in $25-60 \%$ of barren mares and is one of the main reasons for reduced fertility in the mare (Troedsson 1999, Leblanc et al. 2007, Overbeck et al. 2011). Equine endometritis is caused by the introduction of semen, bacteria, fungi, yeasts, air or urine into the mare's uterus. Susceptible mares with a defective perineal conformation or cervical incompetence, reduced myometrial activity and uterine immune response respond to a uterine contamination with facultative pathogenic bacteria such as Streptococcus zooepidemicus or Escherichia coli with persistent endometritis.

Clinical diagnosis is made through the observance of vaginal discharge, short inter-oestrus intervals and ultrasonographical detectable endometrial hyperedema and retention of uterine fluid with varying volume and character. Clinical findings are substantiated by inflammatory uterine cytology (Knudsen 1964, Wingfield Digby and Ricketts 1982, Riddle et al. 2007, Leblanc and Causey 2009) and positive uterine culture (Dimmock and Edwards 1923, Brook 1984, Riddle et al. 2007). Collecting samples from the uterus is a routine practice in the assessment of uterine health. Samples can be collected by single- or double-guarded swab, brush, low-volume lavage and endometrial biopsy (Wingfield Digby and Ricketts 1982, Bourke et al. 1997, Aguilar et al. 2006, Leblanc et al. 2007, Riddle et al. 2007, Defontis et al. 2011, Overbeck et al. 2011 , Walter et al. 2012, Christoffersen et al. 2015).

The bacteriological examination of endometrial swabs is one of the most common methods for diagnosing endometritis in the mare (Dimmock and Edwards 1923, Riddle et al. 2007). The vagina and particularly the vestibulum and clitoral fossa harbor a variety of facultative uterine pathogens (Hinrichs et al. 1988). These bacteria maybe introduced into the uterine environment during the swabbing procedure, cause contamination of endometrial samples and endometritis. Therefore the technique and the type of the culture instrument are essential for the results of uterine culture swabs and reproductive health.

Guarded culture instruments reduce contamination of the swab itself during the most common transvaginal manual 
swabbing technique (Allen and Newcombe 1979, Blanchard et al. 1981, Ricketts 1981), but endometrial contamination via the outside of the guard may still occur and lead to falsepositive uterine culture results and uterine contamination. Traditional sampling by speculum and forceps allows introduction of the swab through the cervical opening without contact to the vulvovaginal area. This technique was recommended by Waelchli et al. (1992) and Handler (2005). However, swabbing with the speculum may show the risk of pneumovagina or air insufflation into the cervix, which may lead to uterine bacterial contamination and endometritis (Caslick 1937, Götze 1952, Thornbury 1975, Slusher 1986, Ricketts and Curnow 1988).

Few evidence-based information is available about the contamination risk of nowadays most commonly used doubleguarded swabs taken manually transvaginal or by speculum and forceps. Guidelines published by the German Society for Equine Medicine prefer sampling by speculum and forceps (Bartmann et al. 2013). Täte (2011) compared the transvaginal manual sampling technique and the sampling with speculum and cervical forceps. The manual transvaginal sampling method revealed significantly more often bacterial growth than samples taken by speculum and forceps $(p<0.0001)$.

Recently, a rigid LED lightning endoscope equipped with a waterproof monitor and two working channels 16 and $10 \mathrm{~mm}$ diameter) was introduced to the bovine and equine practice (iVetscope ${ }^{\circledR}$, Fa. Quldee, Homberg/Ohm, Germany). It allows quick and easy to handle endoscopy of the reproductive tract, larynx and oral cavity. The iVetscope ${ }^{\circledR}$ has been used for uterine culture swabbing and introduction of a cytobrush through the $10 \mathrm{~mm}$ diameter working channel under visual control in bovine practice.

The objective of the present study was to compare uterine culture swabbing by transvaginal manual sampling, speculum and forceps and via iVetscope ${ }^{\circledR}$ with regard to bacterial growth, category of bacterial growth (no bacterial growth, apathogenic bacterial growth, facultative bacterial growth and samples with combined growth of apathogenic and pathogenic bacterial growth), number of different bacterial species in one sample and degree of bacterial growth in relation to uterine cytology.

A second double-guarded uterine culture swab and doubleguarded cytobrush sample were taken 48 hours after the first sampling to evaluate the hygienic risk of uterine bacterial contamination by the three swabbing techniques.

The aim of the study was to identify the most reliable swabbing method which reduces the risk of sample and uterine contamination.

\section{Materials and methods}

\section{Animals and sampling groups}

Eighty-eight estrous mares of different age (1 $1.6 \pm 4.8$ years) and reproductive history were included in the study in a commercial breeding program from March to July 2016. According to their reproductive history mares were divided in "assu- med genitally healthy" $(n=37$; maiden $(n=13)$, barren $(n=12)$, foaling mares $(n=12))$ and "assumed subfertile" $(n=51$; not pregnant in one cycle $(n=15)$, not pregnant in two cycles $(n=12)$, resorption $(n=12)$, genital catarrh $(n=12))$. Mares from each group were assigned at random to one of three sampling groups. Following a gynecological examination double-guarded uterine culture swabs and double-guarded cytobrush samples to assess cytology were obtained "transvaginal manually" (MAN) ( $=29)$, by "speculum" (SPEC) ( $n=29)$ or via "iVetscope ${ }^{\circledR "}$ (SCOP) ( $\left.=30\right)$ during estrous (estrous behaviour, $>30 \mathrm{~mm}$ follicle, uterine edema). A second double-guarded uterine culture swab and doubleguarded cytobrush sample were taken 48 hours after the first sampling.

\section{Equipment and procedures for sample collection}

The mares were restrained in an examination stock. Following a transrectal ultrasonographic examination the tail was wrapped and covered by a glove (Fa. WDT, Garbsen). The vulva and perineal region was rinsed with warm water, scrubbed with Degraseptin (Degraseptin, Fa. Animedica, Senden), rinsed again three times and dried with paper towels.

A double-guarded uterine culture swab and a double-guarded cytobrush sample to assess cytology were obtained by three different sampling methods.

In the MAN-group the double-guarded uterine swab and cytobrush were passed manually with a sterile glove through the cervical channel into the uterine body. In the SPEC-group a sterile spreadable Polansky-speculum was inserted into the vagina, the external cervical os fixed with forceps by Götze modified by Albrechtsen and the double-guarded uterine swab and subsequent cytobrush introduced through the cervix under visual control with an electric torch. In the SCOP-group a rigid endoscope equipped with a monitor (iVetscope ${ }^{\circledR}, \mathrm{Fa}$. Quldee, Homberg/Ohm, Germany) (Fig. 1) was introduced into the vagina, protected by a sterile sleeve $(50 \times 5 \mathrm{~cm}$, Heißluft Rolle Typ HR, Fa. Steriking, Pattensen). When the outer cervical os was displayed on the monitor, the sterile sleeve was pushed back and the double-guarded swab and subsequently the double-guarded cytobrush introduced through the working channel of the iVetscope ${ }^{\circledR}$.

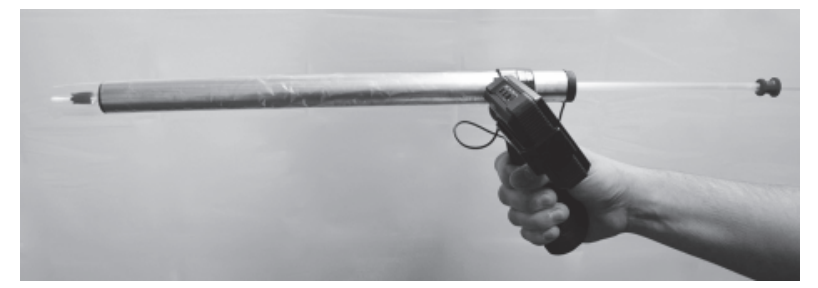

Fig. 1 iVetscope ${ }^{\circledR}$ Fa. Quldee, Homberg/Ohm with a double guarded swabbing system Fa. Minitüb, Tiefenbach

In all three sampling groups the swab and the cytobrush were kept in contact with the endometrium for 30 secs. A second set of double-guarded uterine culture swab and cytobrush were taken in the same approach 48 hours after the first sampling to examine the effect of contamination of the three sampling methods. 


\section{Microbiology}

The uterine culture swab was carefully removed from the double-guarded sampler and transferred into AMIES ${ }^{\circledR}$ transport medium and transported overnight to an internationally accredited laboratory (Labor Dr. Böse, Harsum, Germany). The swab samples were smeared on Columbia agar, Columbia agar with colistin and aztreonam and a Gassner agar (Oxoid, Deutschland $\mathrm{GmbH}$ Wesel). Inoculation in an enrichment medium (Müller-Hinton Medium) followed. All samples were incubated for 24 hours at $37^{\circ} \mathrm{C}$, evaluated for bacterial growth (mild, moderate, severe), incubated for another 24 hours at $37^{\circ} \mathrm{C}$ and re-examined. For further culture differentiation a MALDI- TOF microflex ${ }^{T M}$ (Fa. Bruker, Bremen) was used, if necessary. The uterine culture swabs were analyzed with regard to bacterial growth, combination of different bacteria in one sample and degree of bacterial growth and bacterial categories (samples with no bacterial growth, samples with apathogenic bacteria, samples with facultative pathogenic bacteria, samples with apathogenic and facultative pathogenic bacteria). Facultative pathogenic bacteria included Bacteroides fragilis and ureolyticus, B-hemolytic Streptococcus, Clostridium perfringens, Escherichia coli hemolytic, Klebsiella pneumoniae spp. pneumoniae, Pseudomonas aeruginosa, Staphylococcus aureus, Taylorella equigenitales, Candida tropicalis.

Apathogenic bacteria included $\alpha$-hemolytic Streptococcus, nonhemolytic Streptococcus, Aspergillus terreus, aerobic spore-formers, Corynebacterium ssp., Coitrobacter farmeri, Enterobacter spp., Escherichia coli nonhemolytic, Flavobacterium spp., Proteus ssp., Pseudomonas putida, Pseudomonas koreensis, Micrococcus, Candida pelliculosa, Pantoea agglomerans, Staphylococcus ssp..

Samples with facultative pathogenic bacteria - with or without combined apathogenic bacteria - were opposed to samples with no facultative pathogenic bacteria (including samples with no bacterial growth and samples with solely apathogenic bacteria.

\section{Cytology}

The Cytobrush was smeared on a microscopic glass slide $(76 \times 26 \mathrm{~mm}$, Fa. Roth, Karlsruhe) which was dried at room temperature, fixed by M-FIX (Merckofix, Fa. Merck, Darmstadt) and stained by Diff-Quick ${ }^{\circledR}$ (Dip Quick Stain Fa. Jorgensen, Colorado). The slide was examined by light microscopy (400 $\times$ magnification) for the presence of PMN-cells. A minimum of 200 cells were counted and more than 5 PMN- cells per 10 high power fields was considered positive for endometritis (Dascanio 2003).

\section{Statistics}

Distributions of characteristic categories of the isolated bacteria, degree of bacterial growth and number of bacteria per sample were evaluated by Fisher-exact-Test/Chi-Square Test. McNemar-Test $(2 \times 2$ table) or Bowker-Test ( $\geq 3 \times 3$ table) were used to proof paired samples of symmetry like types of bacteria and degree of bacterial growth for the time points 0 and 48 hours. To evaluate differences between the number of bacteria per sample at two time points Wilcoxon-Test was used. Kruskal-Wallis-Test calculated differences between methods used for endometrial sampling at different time points.

\section{Results}

\section{Bacterial growth}

Including all sampling methods and mares, bacteria were isolated in 63/88, $71.6 \%$ mares at the first endometrial sampling. 48 hours after the first endometrial swabbing 70/88, $79.5 \%$ mares showed bacterial growth $(p=0.38)$.

Comparing the three different sampling methods, bacterial growth was detected in 24/29, $82.8 \%$ and 28/29, $96.6 \%$ mares in the MAN-group at the first and second sampling, respectively. Significantly fewer mares showed bacterial growth in swabs taken by the iVetscope ${ }^{\circledR}(16 / 30,53.3 \%)$ in the first sampling $(p=0.047)$. 48 hours later bacterial growth was significantly more often detected in the MAN-group compared to the SPEC-group $(22 / 29,75.9 \% ; p=0.02)$, and SCOP-group $(20 / 30,66.7 \% ; p=0.03)$

Facultative pathogenic bacteria - with or without combined apathogenic bacteria - were obtained from 11/88 mares $12.5 \%$ and $25 / 88,27.3 \%$ mares at the first and the second sampling, respectively $(p=0.008)$. Comparing the three different sampling methods, 7/29, 24.1\% samples showed facultative pathogenic bacteria in the MAN-group in sample 1 , whereas only $1 / 30$ samples in the SPEC-group contained facultative pathogenic bacteria $(p=0.04)$. 48 hours after the first sampling, samples taken manually $(16 / 29,55.2 \%)$ showed significantly more often growth of facultative pathogenic bacteria than samples taken by speculum $(5 / 29,17.2 \%$; $p=0.02)$ or iVetscope ${ }^{\circledR}(4 / 30,13.3 \% ; p=0.08)$ (Table 1$)$.

\begin{tabular}{|c|c|c|c|c|c|c|c|c|}
\hline Category & & & & & & & & \\
\hline & Sample 1 & Sample 2 & Sample 1 & & mple 2 & & mple 1 & Sample 2 \\
\hline No facultative pathogenic bacteria & $22(75.9 \%)^{a}$ & $13(44.8 \%)^{a}$ & $27(90 \%)^{a, b}$ & 26 & $(86.7 \%)^{b}$ & 28 & $(96.6 \%)^{b}$ & $24(82.8 \%)^{b}$ \\
\hline Facultative pathogenic bacteria & $7 \quad(24.1 \%)^{a}$ & $16(55.2 \%)^{a}$ & $(10 \%)^{a, b}$ & 4 & $(13.3 \%)^{b}$ & 1 & $(3.4 \%)^{b}$ & $5(17.2 \%)^{b}$ \\
\hline
\end{tabular}

$a: b$ statistically significant difference between swabbing techniques within time of swabbing 
Most commonly isolated were Staphylococcus species (25.3\%), $\alpha$-hemolytic Streptococci (14.6\%), $\beta$-hemolytic Streptococci (11.7\%) and non-hemolytic Escherichia coli $(9 \%)$. If more than three different bacteria were present, the result was recorded as contamination (8\%).

\section{Combination of different bacteria}

Differentiation of bacterial growth revealed differences in the variety of bacteria in one sample (Figure 3).

As more than three different bacteria in one sample was defined as contamination, two groups were formed $(0-3$ vs $4-6$ bacteria) to analyze the number of bacteria isolated per sample.

From samples taken manually significantly more samples $9 / 29,31 \%$ and $11 / 29,37.9 \%$ showed bacterial growth of more than three bacterial species at the first and second sampling respectively than in samples in the SCOP-group (1/30, $3.3 \%$, and $0 / 30,0 \%$, and SPEC-group $(0 / 29,0 \%$, and 2/29, 6.9\%) (Table 2).

\section{Degree of bacterial growth}

Growth of each bacterium was differentiated in mild, moderate and severe. $7 / 147,4.8 \%$ bacterial species isolated in all

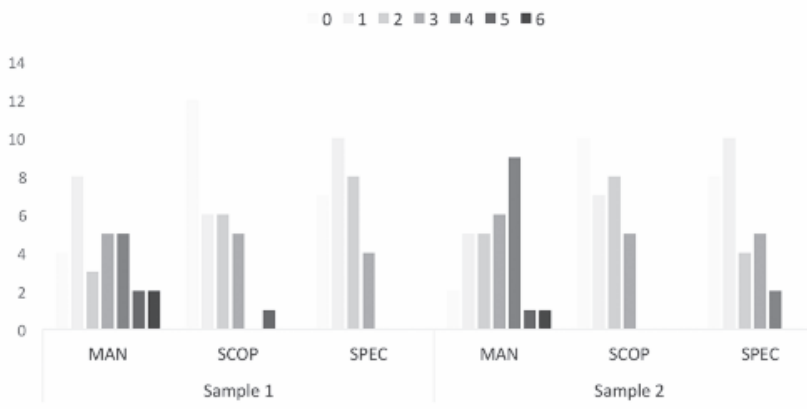

Fig. 2 Number of swabs with the number of bacteria isolated per sample (0-6) regarding sampling method manually (MAN) $(n=29)$, by iVetscope (SCOP) $(n=30)$ and by speculum (SPEC) $(n=29)$ at the first (Oh -Sample 1) and the second sampling (48h - Sample 2) Anzahl der Tupfer mit der aus ihnen isolierten Anzahl an Bakterien je Entnahmetechnik; manuell (MAN) ( $n=29)$, mit iVetscope (SCOP) $(n=30)$ und mit Spekulum (SPEC) ( $n=29)$ zum Zeitpunkt der ersten Entnahme (Oh - Probe 1) und zum Zeitpunkt der zweiten Entnahme (48h - Probe 2) samples and mares at the first sampling showed severe bacterial growth, 9/147, 6.1\% showed moderate and 131/147, 89.1\% mild growth. 48 hours after the first sampling the bacterial growth generally increased to $21 / 159,13.2 \%$ bacteria with severe growth, 24/147, 15.1\% with moderate and $114 / 147,71.7 \%$ with mild bacterial growth.

Comparing the three sampling techniques, significantly more results of mild bacterial growth were isolated from swabs taken manually 63/131, 48.1\% compared to the SCOPgroup $(33 / 131,25.2 \% ; p=0,0022)$ and the SPEC-group $(35 / 131,26.7 \% ; p=0,0047)$ at the first sampling.

48 hours after the first sampling moderate bacterial growth was significantly more often observed in samples taken manually $17 / 24,70,8 \%$ than in the SCOP-group $(3 / 24$, $12.5 \% ; p=0.0017)$ and SPEC-group (4/24, 16,7\%; $\mathrm{p}=0,0046)$. Furthermore severe bacterial growth resulted more often from swabs taken manually $(18 / 21,85,7 \%)$ than taken by iVetscope ${ }^{\circledR}(0 / 21,0 \% ; p<0,0001)$ or speculum $(3 / 21,14,3 \% ; p=0,0011)$ at the second sampling.

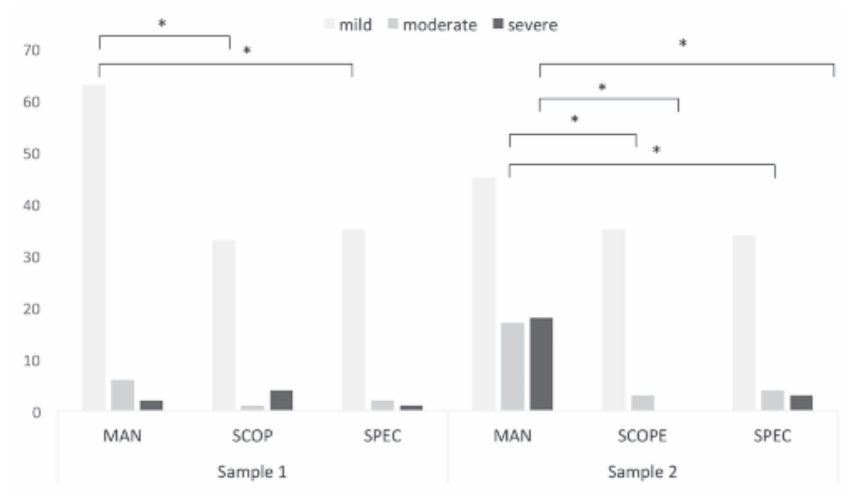

Fig. 3 Number of bacteria isolated with a degree of mild, moderate and severe growth for each sampling method manually (MAN) (a number of 151 bacteria isolated), by iVetscope (SCOP) (a number of 76 bacteria isolated) and by speculum (SPEC) (a number of 79 bacteria isolated) at the first (Oh - Sample 1) and the second sampling (48h - Sample 2) $p<0.05$; *statistically significant difference between swabbing techniques within time of swabbing Anzahl isolierter Bakterien mit geringgradigem, mittelgradigem und hochgradigem Wachstum je Entnahmetechnik; manuell (MAN) (151 Bakterien wurden isoliert), mit iVetscope (SCOP) (76 Bakterien wurden isoliert) und mit Spekulum (SPEC) (79 Bakterien wurden isoliert) zum Zeitpunkt der ersten Entnahme (Oh - Probe 1) und zum Zeitpunkt der zweiten Entnahme (48h - Probe 2) p<0.05; *statistisch signifikante Unterschiede zwischen den Entnahmetechniken zum Zeitpunkt der Probenentnahme

Table 2 Number of swabs with 0-3 and 4-6 bacteria isolated per sample for each sampling method manually (MAN) ( $n=29)$, by iVetscope (SCOP) ( $n=30)$ and by speculum (SPEC) $(n=29)$ at the first (Oh - Sample 1) and the second sampling (48h - Sample 2$)^{*} p<0.05$.

Anzahl der Tupfer aus denen 0-3 und 4-6 Bakterien isoliert werden konnten je Entnahmetechnik; manuell (MAN) ( $n=29)$, mit iVetscope (SCOP) $(n=30)$ und mit Spekulum (SPEC) ( $n=29)$ zum Zeitpunkt der ersten Entnahme (Oh - Probe 1) und zum Zeitpunkt der zweiten Entnahme (48h - Probe 2) ${ }^{*} p<0.05$.

\begin{tabular}{|c|c|c|c|c|c|c|c|c|}
\hline \multirow[t]{2}{*}{ Number of isolated bacteria } & \multicolumn{2}{|c|}{$\begin{array}{l}\text { MAN } \\
n=29\end{array}$} & \multicolumn{3}{|c|}{$\begin{array}{l}\text { SCOP } \\
n=30\end{array}$} & \multicolumn{3}{|c|}{$\begin{array}{l}\text { SPEC } \\
n=29\end{array}$} \\
\hline & Sample 1 & Sample 2 & & ample 1 & Sample 2 & Sample 1 & & ample 2 \\
\hline $0-3$ & $20 \quad(69 \%)$ & $18(62.1 \%)$ & 29 & $(96.7 \%)$ & 30 (100\%) & $29(100 \%)$ & 27 & (93.1\%) \\
\hline $4-6$ & $9 \quad(31 \%)^{a}$ & $11(37.9 \%)^{a}$ & 1 & $(3.2 \%)^{b}$ & $0(0 \%)^{b}$ & $0 \quad(0 \%)^{b}$ & 2 & $(6.9 \%)^{b}$ \\
\hline
\end{tabular}

$a: b$ statistisch signifikante Unterschiede zwischen den Entnahmetechniken zum Zeitpunkt der Probenentnahme 


\section{Cytology}

10/88, $11.4 \%$ mares were positive (>5 PMNs/10 HPF) in the first cytology sample and $9 / 88,10.2 \%$ were positive in the second sample. Regarding the sample method $3 / 10$ and $3 / 9$ positive samples were in the SCOP-group, 4/10 and 4/9 in the SPEC-group and $3 / 10$ and 2/9 positive in the MANgroup at the first and second sampling, respectively.

\section{Discussion}

Collecting endometrial swabs for microbiological examination is a routine practice in the assessment of uterine health and a most common method for diagnosing endometritis in the mare (Dimmock and Edwards 1923, Riddle et al. 2007).

An important complication observed over the years using these standard procedures has been the presence of false-positive or false-negative results. Accurate diagnosis of endometritis and identification of pathogens involved are necessary to choose the correct treatment to optimize fertility. Simultaneously, it reduces the risk of "over-treatment" and bacterial resistance development, which advances more and more in the focus of veterinary medicine.

Several studies recently compared the reliability of different diagnostic methods. They compared results of bacterial culture from endometrial swabs and biopsy (Nielsen 2005, Overbeck et al. 2011) and evaluated the results of low volume lavage samples in relation to endometrial cytology (Leblanc et al. 2007, Christoffersen et al. 2015). The presence of polymorphnuclear neutrophils (PMNs) is considered the "gold standard" when determining whether the diagnostic test result was true or false.

However, the technique of endometrial swabbing in the mare is neglected in equine reproductive research. Due to its practicability, the transvaginal manual swabbing method has gained widespread use in equine practice. Solely, Waelchli et al. (1992) and Täte (2011) compared the transvaginal manual sampling technique and the sampling with speculum and cervical forceps. Waelchli et al. (1992) experimentally contaminated the vulvovestibular area with a liquid culture of a streptomycin resistant strain of Escherichia coli as a marker of contamination of endometrial culture swabs. 22 of 24 endometrial swab specimens from 12 mares were contaminated with the experimental bacterial strain when swabs were taken manually. When a speculum was used only three of 12 swabs from 12 mares were contaminated by the experimental marker $(p<0.05)$. In Täte's study $(2011)$ the manual transvaginal sampling method revealed significantly more often bacterial growth than samples taken by speculum and forceps $(p<0.0001)$.

The purpose of this study was to compare uterine culture swabbing by transvaginal manual sampling, speculum and forceps and via iVetscope ${ }^{\circledR}$ to identify the most reliable swabbing method which reduces the risk of sample and uterine contamination.

All three sampling techniques were performed with a doubleguarded swab and cytobrush, which reduces the risk of contamination (Allen and Newcombe 1979, Blanchard et al.
1981, Aguilar et al. 2006). However, Täte (2011) isolated bacterial growth from a double-guarded swab, which was introduced transvaginally manual into the mare's uterus without opening of the inner sheath. The same experiment performed by swabbing with a speculum and forceps did not lead to bacterial growth. Furthermore, the perineal region and vulva has been rinsed with warm water, scrubbed with Degraseptin, rinsed again three times and dried with paper towels before the swabbing techniques were performed to reduce contamination.

Including all sampling methods and mares, bacteria were isolated in $71.6 \%$ mares at the first endometrial sampling. This high rate of positive uterine cultures is in accordance to $\mathrm{Neu}$ berg (2009) who observed $74 \%$ positive culture samples by double-guarded, transvaginal manual swabbing. Other authors report bacterial growth in 10-50\% of endometrial swabs (Leidl et al. 1976, Merkt et al. 1987, Ricketts and Makkintosh 1987, Hinrichs et al. 1988, Huchzermeyer 2003, Nielsen 2005, Riddle et al. 2007). These divergent observations might result from different microbiological tests and evaluation criteria (A/bihn et al. 2003). Furthermore most studies involved genitally healthy, fertile mares whereas the present studies included mares of different reproductive history (37 "assumed genitally healthy" maiden $(n=13)$, barren $(n=12)$ and foaling mares $(n=12)$ and 51 "assumed subfertile" mares, which were not pregnant in one cycle $(n=15)$ or two cycles $(n=12)$, had a previous resorption $(n=12)$ or genital catarrh $(n=12)$.

The three different sampling methods showed significant differences in bacterial growth, especially in the second sampling after 48 hours. While $97 \%$ of MAN-samples showed bacterial growth, bacteria were isolated from $76 \%$ of SPECand $67 \%$ of SCOP-samples ( $p<0.05)$. Waelchli et al. (1992) observed $92 \%$ positive samples after transvaginal, manual sampling and $25 \%$ positive samples by speculum in the contamination experiment.

Even more striking were the differences with regard to the facultative pathogenic bacteria. Especially at the second sampling significantly more facultative pathogens were isolated from swabs taken manually (55.2\%) compared to swabbing by iVetscope ${ }^{\circledR}(13.3 \%)$ or speculum $(17.2 \%)(p<0.05)$.

But not only the increase in bacterial growth and growth of facultative pathogenic bacteria in swabs taken at the second sampling support the hypothesis of bacterial contamination through the different swabbing techniques. Furthermore the variety of bacterial species and the degree of bacterial growth underline the relevance of the swabbing method.

Some authors define mixed cultures of different bacterial species as contamination and exclude them from microbiological diagnosis (Ricketts 1981, Nielsen 2005). Others consider mixed cultures relevant (Albihn et al. 2003, Leblanc et al. 2007, Wittenbrink et al. 2008). A mixed culture of two bacteria was isolated from mares, which showed a positive cytology (Riddle et al. 2007). Recently bacterial growth of more than two bacteria was considered contamination (Nielsen 2005, Riddle et al. 2007, Christoffersen et al. 2015). The internationally accepted laboratory which analyzed the culture swabs in the present study defines more than three bacteria in one sample as contamination. 
From samples taken manually significantly more samples (31\% and $37.9 \%$ ) showed growth of more than three bacterial species at the first and second sampling respectively than in samples in the SCOP-group (3.3\% and $0 \%$ ) and SPECgroup $(0 \%$ and $6.9 \%)$, which strongly supports contamination of transvaginally taken manual swabs $(p<0.01)$.

Although comparisons with previous studies regarding degree of bacterial growth is difficult due to different laboratory tests and evaluation criteria, the significantly increased number of samples with moderate and severe bacterial growth in the MAN-group, especially 48 hours after the first sampling, confirms bacterial diversion from the caudal reproductive tract and contamination. Hinrichs et al. (1988) demonstrated that endometrial swabbing can lead to bacterial contamination of the uterus, which might be caused by air insufflation or bacterial contamination from the caudal reproductive tract. The results of the present study strongly confirm increased contamination in the MAN-group despite of intensive cleaning of the vulva and perineal area, application of double-guarded swabbing systems and sterile gloves.

Regarding endometrial cytology, the number of mares with $>5$ PMNs/10 HPF did not increase between the first and second sampling. To examine the relevance of bacterial contamination of the uterus by different swabbing techniques during oestrus, it would be interesting to further examine the bacterial growth and cytology at the end of oestrus. In resistant oestrus mares (estrous behaviour, $>30 \mathrm{~mm}$ follicle, uterine edema) a persistent endometritis due to the bacterial contamination is unlikely. However, susceptible mares with a cervical incompetence, reduced myometrial activity and uterine immune response might respond to a uterine contamination with persistent endometritis.

In conclusion, the results of the present study strongly recommend endometrial swabbing by instrumental techniques, speculum and forceps, or iVetscope ${ }^{\circledR}$ in our study. Although these swabbing techniques might be more time consuming in handling and cleaning and require more material, the significantly reduced bacterial contamination is worth the trouble.

\section{Authors' contributions}

$H S$, RB, and KS designed the study. KS, GM, SP, WH, and KR performed the research. KS, JS and HS wrote the manuscript. All authors were involved in discussing and interpreting the data described in this study, critically read the manuscript, and approved the final version of the manuscript.

\section{Acknowledgments}

The study was kindly supported by the foundation of the stud farm Fährhof.

\section{Animal Welfare Statement}

The study was approved by the Lower Saxony State Office for Consumer Protection and Food Safety Hannover (reference number 33.19-42502-05-15A586). Furthermore, procedu- res and maintenance of animals was according to German animal welfare legislation.

\section{Conflict of interest statement}

The authors exclude any possible conflict of interest in regard to the medical products or technology used in the study.

\section{References}

Aguilar J., Hanks M., Shaw D. J., Else R., Watson E. (2006) Importance of using guarded techniques for the preparation of endometrial cytology smears in mares. Theriogenology 66, 423-430

Albihn A., Baverud V., Magnusson U. (2003) Uterine microbiology and antimicrobial susceptibility in isolated bacteria from mares with fertility problems. Acta Vet. Scand. 44, 121-129

Allen W., Newcombe J. (1979) Aspects of genital infection and swabbing techniques in the mare. Vet Rec. 104, 228

Bartmann C., Böse R., Bostedt H., Eversfield S., Fischer J., Genn H., Schüle E., Sieme H., Wehrend A. (2013) Zur Sorgfalt bei der gynäkologischen Untersuchung des Pferdes, Auswahl aktueller Leitfäden zu häufigen tierärztlichen Tätigkeiten in der Pferdepraxis, E. G. f. P. GPM 7-9

Blanchard T. L., Cummings M. R., Garcia M. C., Hurtgen J. P. and Kenney R. M. (1981) Comparison between two techniques for endometrial swab culture and between biopsy and culture in barren mares. Theriogenology 16, 541-552

Bourke M., Mills J. N., Barnes A. L. (1997) Collection of endometrial cells in the mare. Aust. Vet. J. 75, 755-758

Brook D. (1984) Uterine culture in mares. Mod. Vet. Pract. 65, A3-8

Caslick E. (1937) The vulva and the vulvo-vaginal orifice and its relation to genital health of the thoroughbred mare. Cornell Vet. 27, 178-187

Christoffersen M., Brandis L., Samuelsson J., Bojesen A. M., Troedsson M. H., Petersen M. R. (2015) Diagnostic double-guarded lowvolume uterine lavage in mares. Theriogenology 83, 222-227

Dascanio J. (2003) Endometrial cytology. In: Current therapy in equine medicine, Eds; WB Saunders Co, Philadelphia, 226-228

Defontis M., Vaillancourt D., Grand F. X. (2011) Comparison of three methods of sampling for endometrial cytology in the mare. Preliminary study. Tierärztl. Praxis G 39, 171-175

Dimmock W., Edwards P. (1923) Bacteria of the genital tract of mares and the semen of stallions and their relation to breeding efficiency. J. Am. Vet. Med. Assoc. 64, 288-298

Götze R. (1952) Dammrissnaht, Plastik der Vulva und des Scheidenvorhofes bei Stuten und Kuhen. Schaper, Hannover, 4

Handler J. (2005) Gynäkologische Untersuchung bei der Stute. In: Reproduktionsmedizin beim Pferd, C. Aurich, Eds; Parey, Stuttgart, 33-34

Hinrichs K., Cummings M. R., Sertich P. L., Kenney R. M. (1988) Clinical significance of aerobic bacterial flora of the uterus, vagina, vestibule, and clitoral fossa of clinically normal mares. J. Am. Vet. Med. Assoc. 193, 72-75

Huchzermeyer S. (2003) Funktionelle und morphologische Studien über die equine Zervix im Stadium der Ingravidität. Diss. Med. Vet Giessen

Knudsen O. (1964) Partial dilatation of the uterus cause of sterility in the mare Cornell Vet. 54, 423-438

Leblanc M. M., Causey R. C. (2009) Clinical and subclinical endometritis in the mare: both threats to fertility. Reprod. Domest. Anim. 44 Suppl. 3, 10-22

Leblanc M. M., Magsig J., Stromberg A. J. (2007) Use of a low-volume uterine flush for diagnosing endometritis in chronically infertile mares. Theriogenology 68, 403-412

Leidl W., Stolla R., Schels H., Wolpert E. (1976) Keimbesiedlung des Genitale beim Pferd aus klinischer Sicht. Prakt. Tierarzt 57, 214-220

Merkt H., A. Wöckener, T. Heilkenbrinker, M. Zemke, M. M. and Bisping W. U. W. (1987) Mikrobielle Untersuchung in der Stutengynäkologie. Prakt. Tierarzt 68, 5-12 
Neuberg K.-P. (2009) Einsatz der exfoliativen Endometriumszytologie bei Zuchtstuten unter Praxisbedingungen: Vergleich von verschiedenen Entnahmemethoden. Diss. Med. Vet. Giessen

Nielsen J. M. (2005) Endometritis in the mare: a diagnostic study comparing cultures from swab and biopsy. Theriogenology 64, 510-518

Overbeck W., Witte T. S., Heuwieser W. (2011) Comparison of three diagnostic methods to identify subclinical endometritis in mares. Theriogenology 75, 1311-1318

Ricketts S., Curnow E. (1988) Caslick's vulvoplasty for the correction of pneumovagina in mares. In Practice 10, 204-208

Ricketts S. W. (1981) Bacteriological examinations of the mare's cervix: techniques and interpretation of results. Vet. Rec. 108, 46-51

Ricketts S. W., Mackintosh M. E. (1987) Role of anaerobic bacteria in equine endometritis. J. Reprod. Fertil. Suppl. 3, 343-351

Riddle W. T., Leblanc M. M., Stromberg A. J. (2007) Relationships between uterine culture, cytology and pregnancy rates in a Thoroughbred practice. Theriogenology 68, 395-402

Slusher S. (1986) Perineoplasty: a new procedure for surgical correction of abnormal vulvar conformation in mares. Vet. Med. 12, 80

Täte M. (2011) Kulturelle sowie 16S rDNA basierte Untersuchungen der aeroben und anaeroben Keimflora des equinen Uterus. Diss Med. Vet. Hannover

Thornbury R. (1975) Diseases of the vulva, vagina and cervix of the thoroughbred mare. New Zeal. Vet. J. 23, 277-280

Troedsson M. H. (1999) Uterine clearance and resistance to persistent endometritis in the mare. Theriogenology 52, 461-471

Waelchli R. O., Corboz L., Doebeli M. (1992) Streptomycin-resistant Escherichia coli as a marker of vulvovestibular contamination of endometrial culture swabs in the mare. Can. J. Vet. Res. 56, 308-312

Walter J., Neuberg K. P., Failing K., Wehrend A. (2012) Cytological diagnosis of endometritis in the mare: investigations of sampling techniques and relation to bacteriological results. Anim. Reprod. Sci. 132, 178-186

Wingfield Digby N. J., Ricketts S. W. (1982) Results of concurrent bacteriological and cytological examinations of the endometrium of mares in routine stud farm practice 1978-1981. J. Reprod. Fertil. Suppl. 32, 181-185

Wittenbrink M. M., Hoelzle K., Hoelzle L. E. (2008) What's new in bacteriology of the mare's genital tract. Pferdeheilkunde 24, 53-55

Erweiterte Zusammenfassung

\section{Vergleichende Genauigkeit von Entnahmetechniken zur Gewinnung eines Endometriumabstrichs bei der Stute}

Die frühe Diagnose einer Endometritiserkrankung und die Identifikation der Erreger sind essentiell um eine geeignete Therapie einleiten und somit die Fruchtbarkeit der Stute optimieren zu können. Das Ziel dieser Studie war es die Untersuchungsergebnisse uteriner Kulturtupfer, die mit transvaginalmanueller Methode, mit einem Spekulum und einer Zervixfaßzange oder mit einem iVetscope ${ }^{\circledR}$ entnommen wurden, auf das aussagekräftigste Ergebnis hin zu untersuchen. Das iVets- cope $^{\circledR}$ ist eine starre sondenförmige Endoskopröhre mit untersucherzugewandtem Monitor, zwei Arbeitskanälen und einer Kamera mit Lichtquelle für die kombinierte Vaginoskopie und Probenentnahme. Von 88 östrischen Stuten wurden im Anschluss an eine gynäkologische Untersuchung, Abstriche vom Endometrium mit drei verschiedenen Entnahmetechniken durchgeführt. Die Endometriumabstriche wurden mit einem doppeltgeschützten Tupferentnahmesystem mittels manueller Methode (MAN) $(n=29)$, Spekulum und Zervixfaßzange (SPEC) $(n=29)$ und dem iVetscope ${ }^{\circledR}$ (SCOP) $(n=30)$ entnommen. Nach 48 Stunden wurde erneut ein Abstrich vom Endometrium mit einem Tupfer und ein Cytobrush entnommen. Die Ergebnisse der kulturellen Untersuchung wurden durch ein international akkreditiertes Labor ermittelt und mit den Ergebnissen der zytologischen Untersuchung verglichen. Das Ergebnis der zytologischen Untersuchung wurde als positiv bewertet bei mikroskopischem Nachweis von $>5$ polymorphkernigen neutrophilen Granulozyten in 10 Hauptgesichtfeldern (Dascanio 2003).

Zwischen den drei Entnahmetechniken konnten insbesondere zum Zeitpunkt der zweiten Probenentnahme (nach $48 \mathrm{~h}$ ), signifikante Unterschiede im bakteriellen Wachstum ermittelt werden. Während 28/29, 97\% Proben in der Gruppe MAN bakterielles Wachstum zeigten, wurden in der Gruppe SPEC lediglich von 22/29, 76\% Tupfern und in der Gruppe SCOP von 20/30, 67\% Proben Bakterien isoliert $(p<0.05)$. Zum Zeitpunkt der zweiten Probenentnahme wurden fakultativ pathogene Erreger signifikant häufiger aus transvaginalmanuell entnommenen Proben isoliert (16/29, 55.2\%), als aus der Gruppe SPEC (5/29, 17.2\%) und SCOP (4/30, $13.3 \%)(p<0.05)$. Die Gruppe MAN wies zudem sowohl bei der ersten als auch bei der zweiten Tupferprobenentnahme eine signifikant höhere Anzahl von Proben mit mehr als drei Bakterienarten je Probe auf (31\% bzw. 37.9\% in der Gruppe MAN versus $3.3 \%$ bzw. 0\% in der Gruppe SCOP und 0\% bzw. 6.9\% in der Gruppe SPEC bei der ersten bzw. zweiten Probenentnahme $(p<0.01))$. Die erhöhte Anzahl an Mischkulturen mit mehr als 3 Bakterienspezies deutet auf eine bakterielle Kontamination der manuell entnommenen Tupfer aus kaudalen Abschnitten des Reproduktionstrakts hin.

Anhand der Ergebnisse der vorliegenden Studie wird die instrumentelle Entnahme eines Endometriumabstrichs (Spekulum und Zervixfasszange oder iVetscope ${ }^{\circledR}$ ) empfohlen. Auch wenn diese Methoden zeitaufwendiger sind und mehr Equipment benötigen, zeigt die signifikant geringere bakterielle Kontamination die Relevanz der instrumentellen Entnahme eines Endometriumabstrichs in der Pferdepraxis.

Schüsselwörter: Stute, Uterus, Endometriumabstrich, bakterielle Kontamination, Mikrobiologie, Zytologie, Reproduktion 